\title{
よりむらに関する研 究*
}

（第 1 報）リング精紡機に拈けるよりの生成

\begin{tabular}{|c|c|c|c|c|c|}
\hline （昭和 36 年 5 月 30 日受理） & 会員 & 藤 & 野 & 清 & 久** \\
\hline & $"$ & 宇 & 野 & & 稔 \\
\hline & " & 塩 & 見 & & 昭 \\
\hline & " & 柳 & 川 & 良 & 樹 \\
\hline
\end{tabular}

目的

摘

要

リング精紬機における加ねん状態を理論的に考察し，系のよりにおよぼす諸因子の影響を検討する.

成 果

（1）リング精紡機のフロント ローラと，加敉ん点間にある繊維に作用する力の釣合より加ねん現象を解析し，つ ぎの関係式を得た。

紡出張力 $\quad F=\int_{-b}^{+b} \frac{|x-a| l}{\sqrt{l^{2}+(x-a)^{2}}} k_{t} N f(x)(1-p) d x$

よりモーメント $\quad M_{t}=d_{0} \int_{-b}^{+b} \frac{N f(x)(1-p) k_{t}}{4} \cdot \frac{(x-a)^{2}}{\sqrt{ } l^{2}+(x-a)^{2}} d x+\frac{\alpha k_{c}}{4}$

ただし, $f(x)$ はニップ点に沿う座標 $x$ に関する䋐維の分布, $a, l$ はおのおの加敉ん点の $x, y$ 座標, $N$ は全㵶 維数， $d_{0}$ は仮想軸径， $\alpha$ は比例定数， $k_{t}, k_{c}$ は各緎維の引張りおよび圧維に対するばね定数.

（2）得られた理論式により，従来よりに関し経験的に知られている事㝬がよく説明できままたよりむらに影響 する諸风子を明らかにするととができる.

\section{1. 緒言}

紡績系の均質化のため, 最近ドラフトに関する研究が 多く抢てなわれ，またドラフトの自動制御によってむら の減少が計られている，しかし，緔績において，瀻維束 の質量むらを皆無にするととは極めて困難である上，緎 維束はドラフト後に加衫んされ, 总取られるから, 系品 質に㧍よぼす加敉ん工程の影響も決して軽視さるべきで はない。

従来加称ん工程に関する研究としては，バルーン張力 や巻取張力の研究が極めて多いが, 加衫ん工程と系品質 との関係について述べたものは, ほとんど見るととがで きない，一方，系のよりに䦥する文献す数多くをあげる ことができるが，てれらはいずれあフィラメント糸ある いはむらのない均質な模型にもとづいて解析されたもの で, 加权ん工程の影響に触れていないのが普通である. むらのある繊維束とよりとの関係については, 系重量

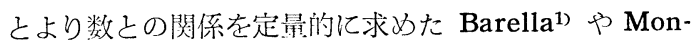
fort ${ }^{2)}$ あるいは， Maillard ${ }^{3)}$ 等の研究があり，また定
性的な解析には㷊4), 石倉 ${ }^{5)}$ や Hannah ${ }^{6}$ ) 等の研究があ る.しかし，てれらも加衫ん工程の影響を述べていない ことでは，他のよりに関する研究と同じである．

筆者等は，精紡機のフロントローラから送り出され た繊維束が, 加权んされる状態を理論的に考察し, 䋊維 束と加敉ん工程との関係を明ら加すると共に, 紡績系 によりむらの生じる原因について考察をててろみた。

\section{2. リング精紡機で より がかかる現象}

一般に瀻維束が加ねんされる形式には，古く Balls ${ }^{7)}$ によって示されたように 2 種ある. 第 1 は引引揃えた針金 の订简状符束を，その軸のまわりによる型式で，集束中 心の針金は常にまっすぐである、第 2 の型式は，針金を 平らに平行に並べたものを仮想軸のまわりに巻きつけた 型式で,各針金のより角度はいずれも同じと見なされる。 Balls は前者のより模型を中奏より (Solid twist), 後 者を平より（Flat twist）またはリボンより（Ribbon twist）之呼び，糸がこれらのいずれの型式でよられる

* Twist Irregularity. Part 1 : Twisting on a Ring Spinning Frame.

* K. Fujino, Member. 就都大学, M. Uno, A. Shiomi, Y. Yanagawa, Member. 尔都工去䋐維大学 
かは,リボンの幅, 張力によって定まり, 平よりは張力 の小なるとき，中実よりは大張力のときに生じると述へ ている

リング精紡機上でドラフトされた織維束が, フロント ローラニップより送り出される場合,纎維束はフロント トップローラとボトムローラ間の圧力で扁平化され, リボン状をなしていると考えられる。このような繊維束 は, 加衩ん直前において横幅方向に圧縮され, 繊維密度 の高い，幅の狭いリボン状に集束されてから，加ねんに とあなって仮想軸のまわりに巻きつくと考えるととがで きる. 実際には加ねん後の横圧力によって, 織維束は系 中心に向って圧縮され，系は中実よりのように充実した あのになるから，一般の系において，このような中空軸 をみとめるととはできない。しかし，精紡系を少し解ね んし，その横断面を観察すれば，第 1 図(a)の綿系 $10 \mathrm{~s}$,
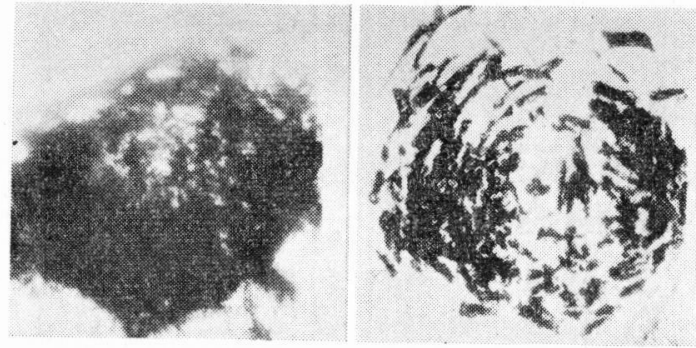

(a) 綿糸 $10 \mathrm{~s}$

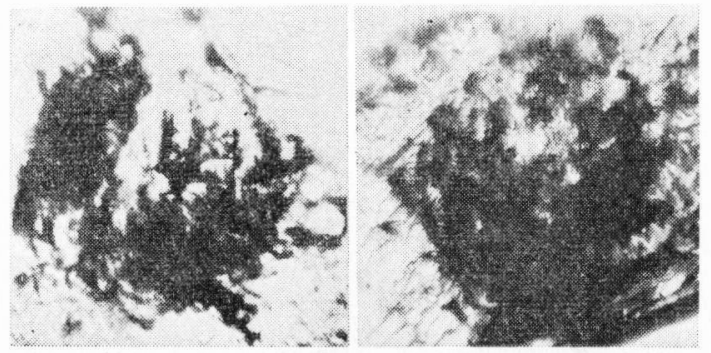

(b) 綿系 $16 \mathrm{~s}$

（第1図）解永んした糸の断面

(b)の $16 \mathrm{~s}$ のように，系中央付近に中空洞がみとめられ， 纎維束はそのまわりにまきついているととがわかる。し たがって, リング精紡機による加ねんは，中実よりでな くリボンよりであると考えるととができるので，以下と れにあとづいて加ねんとこ机に影響する諸因子を理論的 㳊考察する.

\section{3.よりの生成点}

はじめにリボン状をなして送り出された繊維束がよら れより が生成する点の位置を考えて見る.
フロントローラから送り出されたリボン状の繊維束 において,絒維はすべて同一の断面形状,断面積および同 一性質を有するあのと考える. また加ねんされた系の太 さは, フロント ローラニップにおける䄉維束の幅や, ニップと加ねん点間の距離に比して十分小さいと考えれ

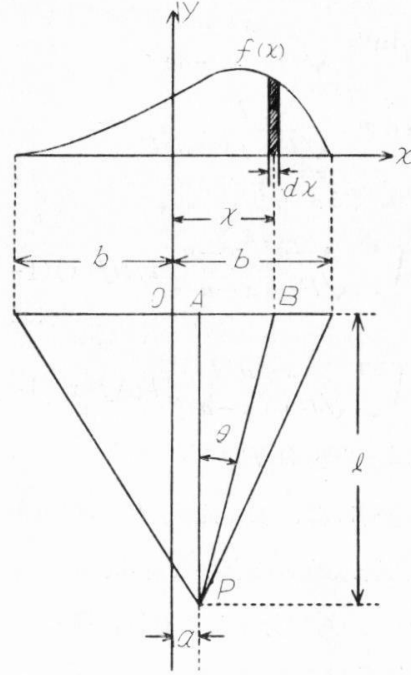

（第2図） ニップ点から加权ん点 までの繊維束の状態

ば，纎維束は第2罒の $P$ で示した一点に集束され，乙 の点で加ねんされると考えるととができる。

座標の原点をニップ点での繊維束の幅 $2 b$ の中央 $O$ に とり, ニップ点に沿って $x$ 軸をとる. またよりの生成 点 (加ねん点) $P$ の座標を $(a, l)$, 繊維端がこの加ねん 三角形の領域に存在する確率を $p$ とし, さらに $f(x):$ ニップ点に抢ける繊維の分布 $\left(\int_{-b}^{+b} f(x) d x=1\right)$

$N$ : ニップ点にある全繊維本数

$l: x$ 軸より加ねん点までの距離

$k_{t} \quad$ ：各繊維の引張りに対するばね定数

とすれば，原点 $O$ より $x$ だけへだたった $B$ におい て, 一端をフロントローラにニップされ, 他端を加ねん 点でつかまれている繊維 $B P$ に働く引張力は, この繊 維の伸びに比例し, その繊維数は $N f(x)(1-p) d x$ と なる。いま近似的に繊維の伸びは, 軸線 $A P$ からの $x$ 座標に比例すると考えれば， $x$ 点にある全繊維に働く引 張力は

$$
k_{t}|x-a| N f(x)(1-p) d x
$$

で与えられる.

よって, $x$ 方向の成分 $X$ は

$$
X=k_{t}|x-a| N f(x)(1-p) d x \cdot \sin \theta
$$

したがって，ローラにニップされる全織維によって $P$ 
点に作用する $x$ 軸方向の力 $H$ は

$$
H=\int_{-b}^{+b} k_{t}|x-a| N f(x)(1-p) d x \cdot \sin \theta
$$

同じく軸線方向の力 $V$ は

$$
V=\int_{-b}^{+b} k_{t}|x-a| N f(x)(1-p) d x \cdot \cos \theta
$$

とこで

$$
\begin{aligned}
& \sin \theta=\frac{x-a}{\sqrt{l^{2}+(x-a)^{2}}} \\
& \cos \theta=\frac{l}{\sqrt{l^{2}+(x-a)^{2}}}
\end{aligned}
$$

$P$ は釣合状㦔にあるから

$$
\begin{aligned}
H & =\int_{-b}^{+b} \frac{|x-a|(x-a)}{\sqrt{l^{2}+(x-a)^{2}}} k_{t} N f(x)(1-p) d x=0 \\
V & =\int_{-b}^{+b} \frac{|x-a| l}{\sqrt{l^{2}+(x-a)^{2}}} k_{t} N f(x)(1-p) d x \\
& =\text { 紡出張力 } F
\end{aligned}
$$

(4)，(5)式を解けば, 加ねん点 $P$ の位置および各纎維 亿作用する力を求めるととができる.

あし $f(x)$ が対称分布であれば，(4)より $a=0$ とな り, 加衫え点 $P$ は分布の対称中心に一致する. $f(x)$ が 非対称分布であれば，その分だけ加ねん点はずれるが,

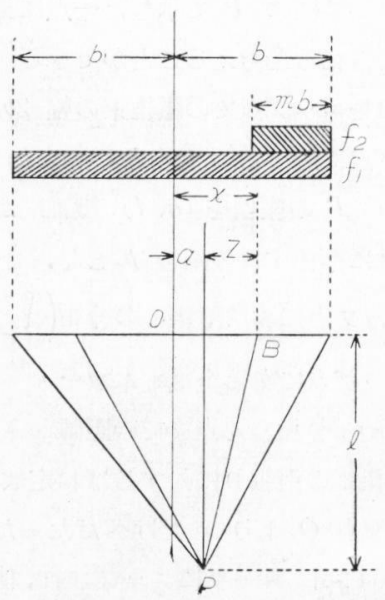

(第3図) ニップ点における繊維分布を モデル化した場合

いま簡単のため $f(x)$ が第 3 図に示すように，一様分布 $f_{1}$ (分布領域 $-b \sim+b$ ) と付加一様分布 $f_{2}$ (分布領 域 $b-m b \sim b)$ よりなる場合について考える.

図において, 座標原点を $(a, O)$ 亿移し, $x-a=z$ と おけば, (4)式は

$$
\int_{-b-a}^{b-a} \frac{|z| z}{\sqrt{l^{2}+z^{2}}} k_{t} N f(1-p) d z
$$

$$
=\int_{-b-a}^{b-a} \frac{|\boldsymbol{z}| \boldsymbol{z}}{\sqrt{l^{2}+z^{2}}} k_{t} N\left(f_{1}+f_{2}\right)(1-p) d z=0
$$

$f_{1}$ については被積分関数は奇関数であるから，(-b $+a)$ より 0 までの積分は 0 より $(b-a)$ までの積分 と打ち消し合う。よって(6)式は簡単となり

$$
\begin{aligned}
& \int_{-b-a}^{-b+a} \frac{z^{2}}{\sqrt{l^{2}+z^{2}}} k_{t} N f_{1}(1-p) d z \\
& \quad+\int_{b-a-m b}^{b-a} \frac{z^{2}}{\sqrt{l^{2}+z^{2}}} k_{t} N f_{2}(1-p) d z=0
\end{aligned}
$$

いま $f_{1}=f_{2}$ とし, $a=n b, l=q b$ とおけば(7)式より

$$
\begin{aligned}
(1-n) & \sqrt{(1-n)^{2}+q^{2}}-\frac{1+n}{2} \sqrt{(1+n)^{2}+q^{2}} \\
- & \frac{1-n-m}{2} \sqrt{(1-n-m)^{2}+q^{2}} \\
+ & \frac{q^{2}}{2} \log \frac{\sqrt{(1-n)^{2}+q^{2}}-(1-n)}{\sqrt{(1+n)^{2}+q^{2}}-(1+n)} \\
& \cdot \frac{\sqrt{(1-n-m)^{2}+q^{2}}+(1-n-m)}{\sqrt{(1-n)^{2}+q^{2}+(1-n)}}=0
\end{aligned}
$$

(8)式において, $q$ の種々の值に対応する $n$ の值は第 4 図の通りである。すなわち，付加分布のひろがりを表

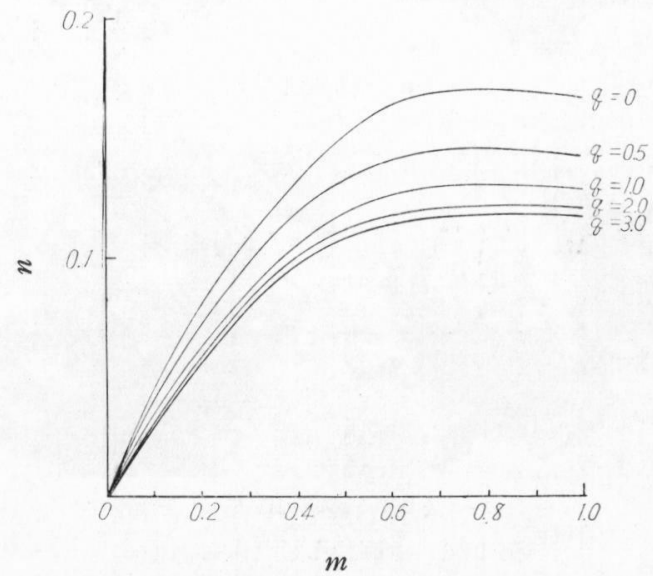

(第4図) 繊維分布による加ねん点の変化

わす $m$ の值が変化しても釣合点 $P$ の位置は $b$ 亿関し てそれほど大きく変化しない。 また $m=0$,すなわち 対称分布の場合， $P$ は対称中心に一致するととが， と の結果からあ明らかである。また，第4図において， $q$ の值が変化しても $P$ の位置はあまり大きく変化しない. いまニップ点に扔いて，最も外侧にある纎維と軸線 $A P$ (第 2 図) とのなす角が系表面でのより角度を表わす と考えれば，より倠は $\tan ^{-1}(b+a) / l=\tan ^{-1} b(1+n) / l$ 
となる. 上述のように， $m, q$ の変化に対して $n$ の值 が小さいから，より㑇度は近似的に $\tan ^{-1} b / l$ で表わす ことができる．したがって，以下の考察には $b$ および $l$ の変化によってより角度変化を表わし,よりの評価をお こなうこととした。

\section{4. よりモーメント}

よりモーメントを求める場合, 前述の仮定のほかに, さらに次の仮定が成立つと考える。

（1）系直径 $d$ は, 絾維数に比例する仮想軸径 $d_{0}$ 之, 各纎維に作用する引張力のうち，軸線に垂直な成分が横 方向のばね定数 $k_{c}$ に働いて定まる部分よりなる.

(2) 系のよりモーメントは各繊維の引張力の合計が系 半径の复のところに作用して生じる。

以上の仮定より，まず系直径を求める．第 2 図におい て, 繊維 $B P$ に作用する引張力の $x$ 軸方向の成分は(1) 式で与えられるが，圧縮力としては常に軸線に垂直方向 に㗢くから，正弦の符号は正のみを考えればよい。した がって

$$
\begin{aligned}
d=d_{0}+\left(\alpha k_{c} / \int_{-b}^{+b} \frac{(x-a)^{2}}{\sqrt{l^{2}+(x-a)^{2}}}\right. \\
\left.\cdot k_{t} N f(x)(1-p) d x\right)
\end{aligned}
$$

ことで, $\alpha=$ 比例定数

よってよりモーメント $M_{t}$ は次式で与えられる。

$$
M_{t}=\frac{d}{4} \int_{-b \sqrt{l^{2}+(x-a)^{2}}}^{+b} k_{t} N f(x)(1-p) d x
$$

(9)式を(10)式に代入すれば

$$
\begin{aligned}
M_{t} & =\left\{d_{0} \int_{-b}^{+b} \frac{N f(x)(1-p) k_{t}}{4}\right. \\
& \left.\cdot \frac{(x-a)^{2}}{\sqrt{l^{2}+(x-a)^{2}}} d x\right\}+\frac{\alpha k_{c}}{4}
\end{aligned}
$$

\section{5. 紡出張力およびよりモーメントの影響}

綃出張力やよりモーメントと加㱛んとの関係は(5)およ び(11)式を解けば求まるが，一例として $f(x)$ が一様分布 $f_{0}$ である場合について求めるとつぎのとおりである.

\section{1 紡出張力の影響}

対称分布のとき $a=0$ であるから，(5)式より

$$
2 \int_{0}^{b} \frac{x l}{\sqrt{l^{2}+x^{2}}} k_{t} N f_{0}(1-p) d_{x}=F
$$

よって

$$
F=2 \phi k_{t} N f_{0}(1-p)
$$

ただし $\quad \phi=l\left(\sqrt{l^{2}+b^{2}}-l\right)$

上式から求めた $\phi$ と $b$ 打よび $l$ の関係を第 5 図に 示す。これからつぎのような結果が得られる。

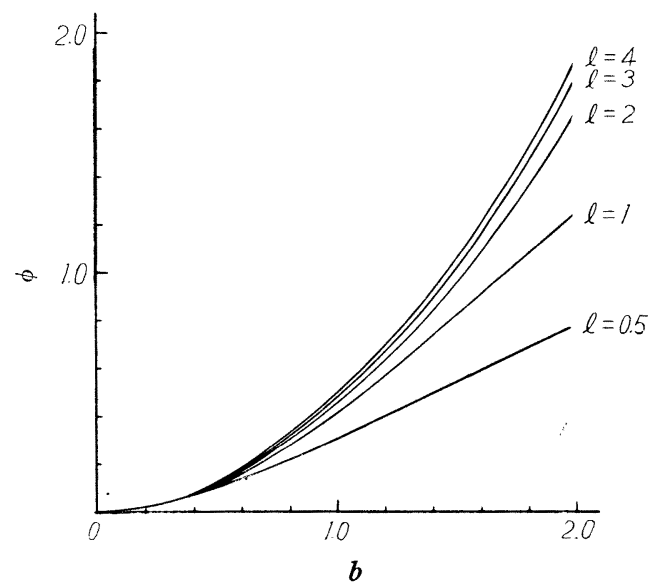

（第 5 図）紡出張力に関する $\phi, b, l$ の関係

（1） $N$ (繊維数）が一定で $\boldsymbol{F}$ (紡出張力）が増加すれ ば $\phi$ が増加する，このとき $b$ が一定か，または減少す れば, $l$ (ニップ点と加ねん点間の距離）は増加しより 角は小となる。 $b$ (ニップにおける繊維束幅）が適当に 増えれば， $l$ の増加と釣合ってより角は一定となる。し たがって， $\boldsymbol{F}$ の変化に応じて $\boldsymbol{b}$ を制御すれば均一なよ りが与えられる。

(2) $F, N, p$ が一定なら $\phi$ む一定. このとき $b$ が 増加すれば $l$ が減少し, より角は大となる.

(3) $F$ が一定で $N$ が増加すれば $\phi$ は減少する。 と のとき $b$ が一定か増加すれば， $l$ は減少する。しかし， よりモーメントに関して後に説明する第 6 四において, $b$ が増加して $l$ が減ると $\Phi$ は增し, 必要モーメントは 増加するので，実際にはこのようなより角まではよられ ない。一般にリング精紡ではよりモーメントはほぼ一定 であるから， $F$ 一定のほかに $M_{t}$ 一定の条件を設けれ ば， $N$ が増えると一般に $b$ は増加し，てのため繊維束 はよられない状態のまま加祊ん可能の $l$ に達してより 角の小さい系となる。すし $N$ が增してあ $b$ を減らす ような制御をおこなえばよりを均一に保つことができ る.

(4) $F, N$ が一定で, 絨維端含有の確率 $p$ が増加す れば, $\phi$ は増加し，より角は小となる.

5.2 よりモーメントの影響

一様分布の場合, 前述のように $a=0$ であるから, 系 直径 $d$ は(9)式より 


$$
d=d_{0}+\frac{\alpha k_{c}}{k_{t} N f_{0}(1-p) \Phi}
$$

また(11)式よりよりモーメント $M_{t}$ は

$$
M_{t}=\frac{N f_{0}(1-p) k_{t} d_{0}}{4} \Phi+\frac{\alpha k_{c}}{4}
$$

ただし， $\Phi=l^{2}\left\{\left(\frac{b}{l}\right) \sqrt{1+\left(\frac{b}{l}\right)^{2}}-\right.$

$$
\left.\log \left(\frac{b}{l}+\sqrt{1+\left(\frac{b}{l}\right)^{2}}\right)\right\}
$$

$\Phi$ と $b$ および $l$ の関係を第 6 図に示す。な打図中に

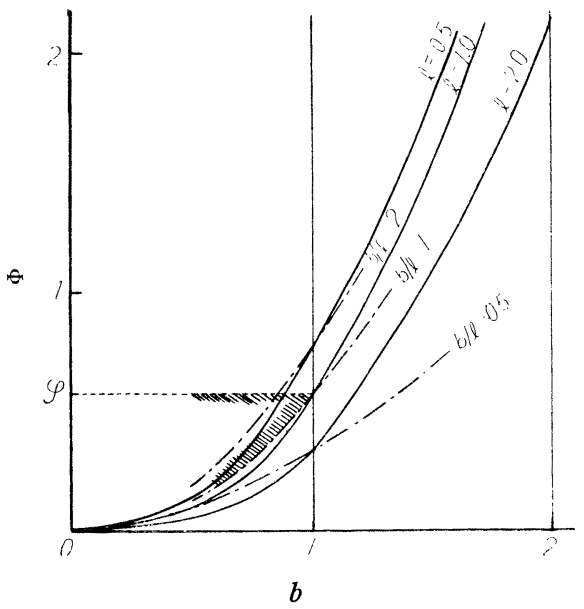

（第 6 図）よりモーメントに関する $\Phi, b, l$ の関係

より角をあらわす $b / l$ 曲線を参考のために示した。 これ からつぎの結果が得られる。

(1) $N$ が一定でよりモーメントが増加すれば， $\Phi$ が 増加する。とのとき $b$ が一定かまたは減少すると, 第 6 図より $l$ が小になり，より角が大となる。 $b$ がある 程度增すと $b / l$ が一定かまたは減少し，より角は小とな る.したがって， $M_{t}$ の増加につれて $b$ を堌せば均一 な糸が得られる。

(2) $M_{t}$ が一定で $N$ が増加すればゅ は小となる。 こ のとき $b$ が増加すると $b / l$ は減少し，より角は小とな る. $b$ がある程度減少すれば $b / l$ が一定か, または堌加 し,より角は大上なる,よって $N$ の増加に対して逆に $b$ を適当に減少させれば均一なよりが与えられる。たと えば，第 6 図の $b / l=1$ なる曲線について， の増加によもなって まで $b$ を減少させれば $b / l=1$ なら均一なより, $b / l>1$ なら強ねんとなり，見掛け太さのむらを少なくした系を 作りうる，逆に $N$ が減少するとき，bを増加させれば
よりを調節するととができる。

(3) $M_{t}$ が一定の場合， $N$ が增えても(14)式より $N f_{0}$ $(1-p) d_{0} \Phi$ は一定である。したがって (13)式の第 2 項は $d_{0}$ に比例し， $d_{0}$ が $N$ に比例して增加するため, 第 1 項の $d_{0}$ と相まって糸直径 $d$ は $N$ に比例して增加す 万。

（4）一般に $N$ が増すと $b$ は堌加するから， $M_{t}$ が 一定なら(2)によってより角が小となり，(3)によって直径 は大となって，太くて甘い系となる。

(5) $M_{t}, b, N$ が一定でも $p$ が増加すれば $\Phi$ は増 加し, $l$ が増加してより角は小よなる。

(6) $N, b$ が一定で $M_{t}$ が增加すれば $\Phi$ は增加し(13) 式から $d$ が小となる。

（7） $k_{c}$ が大になれば系直径は增加する。これは繊維 の配列度が悪いと直径が增加するととを意味する。

一般に紡績系によりのかかる現集は非常に複雑であ るが，以上のように本理諭は加称んされる緎維束の性質 や加敉ん工程因子など，多くの因子の関係走よく説明す るものである。

\section{6. 糸のより数}

前述のより你 $\Theta$ および系直径 $d$ より糸のより数を求 めることができる。いま $\beta$ をよりのピッチとすれば

$\tan \Theta=\pi d / \beta$

単位辰さ当りのより数を $T$ とすれば $T=1 / \beta$ である から

$$
T=\tan \Theta / \pi d
$$

前述の $\tan \Theta=b+a / l$ および(9)式の $d$ 在代入すれば

$$
\begin{aligned}
T & =\left(\frac{b+a}{l}\right) / \\
& \left\{d_{0}+\frac{\alpha k_{c}}{k_{t} N \int_{-b}^{+1)} \frac{(x-a)^{2}}{\sqrt{l^{2}+(x-a)^{2}}} f(x)(1-p) d x}\right\}
\end{aligned}
$$

(15)式に(10)式を代入すれば

$$
T=\left(\frac{b+a}{l}\right) /\left(d_{0}+\frac{\alpha k_{c} d}{4 M_{t}}\right)
$$

したがって， $M_{t}$ が増加すればより数 $T$ が増加する ことがわかる。

7. 吟

味

従来加ねんにもっとあ影響すると考えられた因子は系 の質量であって，たとえば Monfort'2) はそ毛系の重量 とより数の間に -0.47 〜ー 0.87 なる相関係数を得てい る. またてれに類似する研究としては Maillard ${ }^{3)}$, Ba- 
rella1)のあのがあり，前者はそ毛系のより数之断面積 の間に -0.8 の相関係数を得，後者はそ毛系の $1.5 \mathrm{~cm}$ 間の平均值径とより数との間に -0.708 の相関係数を 得ている。乙れらはいずれむよりが系の細い個所に集 まる傾向を定性的に求めたあのであるが，筆者等の研究 によればなぜ系質量とよりの間に 1 亿近い相関係数が得 られないかを理論的に説明することができる.

また，その他の因子，たとえば紡出張力抢よびより モーメントのよりに及ぼす影響については, 従来経験 的に知られているのみであるが，(4)，(5)式およで(11)式を 用いれば理論的に関係づけることができる.

しかし，本報ではニップ点から加㸚ん点までの間の繊 維に㗢く力の釣合より加福ん現象を考察したのみで, バ ルーン領域をへて実際ボビンに巻かれるときのよりに ついては考察していない. 実際には加ねんは他の因子, たとえばトラベラやボビン卷取径の影響をうけるから, これら他因子の影響については次報以下に考慮すること とする。

\section{8. 結 論}

本報ではリング精紡機における加ねんをリボンよりと 考え,フロントローラから加ねん点までの各繊維に働く 力の釣合から加ねん現象を考察し，つぎの理論式をみち びいた。

加福ん点の釣合位置に関し

$$
H=\int_{-b}^{+b} \frac{|x-a|(x-a)}{\sqrt{l^{2}+(x-a)^{2}}} k_{t} N f(x)(1-p) d x=0
$$

紡出張力 $F$ との釣合に関して

$$
F=\int_{-b}^{+b} \frac{|x-a| l}{\sqrt{l^{2}+(x-a)^{2}}} k_{t} N f(x)(1-p) d x
$$

系の直径は

$$
\begin{aligned}
d=d_{0}+\left(\alpha k_{c} / \int_{-b}^{+b}\right. & \frac{(x-a)^{2}}{\sqrt{l^{2}+(x-a)^{2}}} \\
& \left.\cdot k_{t} N f(x)(1-p) d x\right)
\end{aligned}
$$

よりモーメントは

$$
M_{t}=\left\{d_{0} \int_{-b}^{+b} \frac{N f(x)(1-p) k_{t}}{4} .\right.
$$

$$
\left.\frac{(x-a)^{2}}{\sqrt{l^{2}+(x-a)^{2}}} d x\right\}+\frac{\alpha k_{c}}{4}
$$

単位长当りのより数は

$$
T=\left(\frac{b+a}{l}\right) /\left(d_{0}+\frac{\alpha k_{c} d}{4 M_{t}}\right)
$$

これからみちびかれる主な結果はつぎの通りである.

(1) 加ねんには単に繊維本数のみでなく，極めて多く の因子が影響する。

(2) 繊維本数以外の加ねん前の主な因子は, ニップ点 における繊維の分布状態, 平行度, 繊維集合体の引張弾 性，圧縮弾性などである。

(3) 特にニップ点における纎維束のひろがり幅は直接 より角に影響するので, 纎維数の増減に応じてニップ幅 の制御を行なえば,さらに均一な系が得られるである う.

（4）加ねん後の因子としては, 紡出張力, 巻取モーメ ント, 系とトラベラとの摩擦, 卷取張力などがあるが, これらの影響については後報で論じる。

\section{参 考 文 献}

1) A. Barella; "Etudes sur la Torsion des Fils", Belgische Wetenschappelijke Textielannalen, p. 58 (1955-12)

2) Monfort, I.W.T.O.; Tech-Comm., Barcelone (1951)

3) Maillard, Roehrich, Amouroux, I.W.T.O.; Tech. Comm., (1952)

4）森平三郎；“番手斑ある系における撚の分布”, 纎維工業学会誌, 4, p.1（昭13-7）扔よび 4, p.4 （昭13-8）

5）石倉新十郎；“紡績単系の撚に関する理論的解 説”(第 1,2 報), 繊維工業学会誌, 4, p.20 (昭 13-10)

6) M. Hannah ; “The Theory of High Draft", J. Text. Inst., 41, T57 (1950)

7) W. L. Balls ; "Studies of Quality in Cot ton", (1928) London, Mcmillan \& Co., Ltd 